\title{
Empowerment of Rural Women through Self-Help Groups and Value Addition of Millets in Bangalore Rural District of Karnataka, India
}

\author{
A.M. Maruthesha ${ }^{1 *}$, D. Vijayalakshmi ${ }^{2}$ and S.M. Preetham ${ }^{2}$ \\ ${ }^{1}$ Agricultural and Horticultural Research Station, Kathalagere - 577219, Karnataka, India \\ ${ }^{2}$ Department of Food and Nutrition, University of Agricultural Sciences, \\ Bengaluru, Karnataka, India \\ *Corresponding author
}

\section{A B S T R A C T}

\section{Keywords}

Entrepreneurship, Finger millet, Self Help Groups and Value addition

Article Info

Accepted:

17 January 2018

Available Online:

10 February 2018
The present study on socio-economic characteristics, food habits and dietary intake of rural women was conducted in selected villages of Bangalore rural district in Karnataka state. The selected villages were Heggadehalli of Doddballapur taluk and Venkatahalli of Devanahalli taluk during the year 2013-14. The data was collected from the 200 rural women using semi structured interview schedule. The collected data was analysed using appropriate statistical tools. The results of the study revealed that, ten active self-help groups were identified in the selected villages having 19-21 members in each SHG. The total savings of the SHGs ranged from Rs. 10,580 to Rs. 46,080 with average total lending Rs. @ 2\% interest per month ranging from Rs. 720 to Rs. 2,880. Majority of the SHG's had taken loan for the purchase cattle and sheep followed by education loan. Overall 31 per cent of the respondents were engaged in dairy farming followed by vegetable marketing, sheep rearing. Majority of rural women participated in the training on value addition of finger Millet (46\%). After the training programme conducted to the rural women (200) out of which 50 SHG women came forward to take up the entrepreneur activities on value added products of finger millet.

\section{Introduction}

The process of entrepreneurship development involves the entrepreneur as an individual placed in a particular socio-economic sphere where some factors have facilitate role and others inhibitive in her journey to become an entrepreneur (Rashmi and Sinha, 2011).

Entrepreneurs play a pivotal role in economic development. However, the women entrepreneurs are considered to be the most important economic agents for the economic augmentation of any country. It is a wellknown fact that women have played and continued to play key role in conservation of basic life support systems. Hence, entrepreneurship development is a possible approach to empower women. A women as an entrepreneur is economically more powerful than as mere worker, because ownership not only confers control over assets but also gives her the freedom to take decision. This would also uplift her social status in society. The Self 
Help Groups(SHG) in rural India are causing a silent revolution not only in terms of providing micro credit but also by contributing in other forms to make the agriculture sustainable (Savitha et al., 2009).

Empowering women needs a holistic approach to encourage their participation in decision making in the household, community and local domestic sectors and prepare women to take up leadership position in agricultural activities. In this backdrop, the present study aims at understanding the "Empowerment of rural women towards food security through agro processing activities" has been formulated with an objective to know the existing self help groups in the villages and activities taken up by them.

\section{Materials and Methods}

The present study on socio-economic characteristics, food habits and dietary intake of rural women was conducted in selected villages of Bangalore rural district in Karnataka state. The selected villages were Heggadehalli of Doddballapur taluk and Venkatahalli of Devanahalli taluk during the year 2013-14. The villages selected come in the frame work of the project on "Partnering with higher education in India for improving nutritional quality of food by biotechnology approaches" funded by USAID. Ninety rural women from Heggadehalli village and 110 rural women from Venkatahalli village were selected randomly for the study, thus making a total sample of 200 respondents.

A pilot study was conducted to determine the feasibility of the study and validity of the questionnaire. The pilot study was conducted on 10 per cent of the sample Size. The study used both qualitative and quantitative assessment measures. The data was collected from the respondent rural women using semi structured interview schedule developed for the study. The collected data was tabulated and analysed using appropriate statistical tools like frequency, parentage, mean, standard deviation, correlation etc., to draw valid conclusions.

\section{Results and Discussion}

\section{Performances of rural women SHG's}

Existing women SHGs in the study area are presented in Table 1. The women formed SHG's primarily to make savings and pool their limited resources to meet their financial requirements. Among the study villages totally ten SHG were actively involved in various functions. Majority of the SHG groups were having 19-21 members in each group with the collection of Rs.10 per week. Among the SHGs groups, Chandrodaya SHG group and Jaymatha SHG's groups were having highest savings of Rs.46,080 per month, followed by Maheshwari group Rs.38,400 per month. Chandrodaya and Jaymatha SHG groups were functioning for past 6 years, followed by Maheshwari group and majority of the SHG's had taken loan for the purchase cattle and sheep followed by education loan. Women save a small portion of their meager income and pool the money which they lend among themselves at an interest rate decided by the group as a whole. A close look at the pattern of lending shows that, credit facilities were availed for meeting the charges on crop cultivation, purchase of milch animals, sericulture activities, purchasing of tailoring unit and also repayment of loan. Thus most part of the credit was used for improving the sustainability of their agriculture and economic status. These findings are supported from the study conducted by Kavitha and Deepa (2013) and Parvinder et al., (2013).

Base line survey results (Table 2) showed that overall 31 per cent of the respondents were engaged in dairy farming followed by 
vegetable marketing, sheep rearing etc, and only 1.5 per cent were engaged in vermicomposting before training programme on value addition in finger millet. From the study it was clear that none of the respondents had undergone any of the training programmes related to entrepreneurial development.

Training programme was one of the tool for enhancement of skills and value addition activities among the SHG women and also it was helpful for empowerment of SHG members and training programmes enhance the self-confidence, leadership qualities, skills to undertake value addition activities, enhances income, utilisation of protective foods and better knowledge.

Similar findings on mushroom cultivation have entrepreneurial activity among SC/ST rural women as reported by Raguprasad et al., (2008).

\section{Training programmes conducted for rural SHG women}

Training programmes were conducted to 200 rural women at the village level. The results are depicted in Table 3, majority of rural women participated in the training on value addition of finger Millet (46\%) followed by training on utilisation of baby corn/maize in the diet $(16 \%)$, processing of fruits and vegetables $(15 \%)$, processing of tomato based products $(12 \%)$ and cultivation and utilisation of mushroom $(11 \%)$.

These findings are in line with the study conducted by Seema and Bhati (2009) who reported that trainings would be strengthening the women entrepreneurship and also value addition. In the present study training programmes were focused with regard to food safety, hygiene and HACCP. In order to harness the scope for value addition for finger millet in the villages, training was imparted to the rural women and good response was received from the trained members.

After the training programme conducted to the rural women (200) out of which 50 SHG women came forward to take up the entrepreneur activities on value added products of finger millet. Agro-processing machinery was set up in both the villages by procurement of mini dhal mill, sealing machine, sieves, weighing scale, gas stove, apron set, utensils and standard spoon sets, by using these equipments they produced value added products such as finger millet malt, hurihittu and malt chocolate to the extent of $12,288 \mathrm{~kg}, 3,456 \mathrm{~kg}$ and $144 \mathrm{~kg}$ respectively for the duration of two years (Table 4). The production was slightly lower $(5808 \mathrm{~kg})$ in the year 2006 and enhanced to $10,080 \mathrm{~kg}$ in the year 2007.

The production was 1.67 times increased during 2007 compare to 2006 for finger millet malt followed by hurihittu and malt chocolate 2.00 times and the total production increased by 1.73 times in the year 2007 compared to 2006. At the end it was $15,888 \mathrm{~kg}$ for three products.

Nutrient composition of three value added products from finger millet are presented in Table 5. Among the three products, malt chocolate had higher energy $417 \mathrm{Kcal}$ and least amount protein and good amount of fat while normal finger millet malt had $13 \mathrm{gm}$ of protein and $306 \mathrm{mg}$ of calcium. So among the products, finger millet malt proved to be a good source of calcium. The difference in the nutritive value was due to addition of defatted soya flour and skim milk powder to the malt. The results of the study are well supported by the findings of Deshpande et al., (2003), prepared a traditional snack food item hurihittu using green gram with varying levels of soya bean to enhance the nutritional composition. 
Table.1 Existing women self-help groups in the study area

\begin{tabular}{|c|c|c|c|c|c|c|c|c|c|c|}
\hline Name of the & Venkatahalli & & & & & & Heggadeha & & & \\
\hline Name of the SHG & Chandrodaya & Suryodaya & Arunodaya & Kirthini & Nandini & Chandrodaya II & Jaymatha & Maheshwari & Mookambika & SreeShakthi \\
\hline No.of members & 21 & 19 & 19 & 21 & 19 & 21 & 20 & 19 & 21 & 20 \\
\hline $\begin{array}{l}\text { Money } \\
\text { collected/week } \\
\text { (Rs.) } \\
\end{array}$ & 10 & 10 & 10 & 10 & 10 & 10 & 10 & 10 & 10 & 10 \\
\hline $\begin{array}{l}\text { Total savings } \\
\text { (Rs.) }\end{array}$ & 46,080 & 21,600 & 21,600 & 15,360 & 15,360 & 10,800 & 46,080 & 38,400 & 21,600 & 10,580 \\
\hline $\begin{array}{l}\text { Average total } \\
\text { lending Rs. @ } \\
2 \% \text { interest per } \\
\text { month }\end{array}$ & 2,880 & 1440 & 1,440 & 960 & 960 & 720 & 2,880 & 2,400 & 1,440 & 756 \\
\hline $\begin{array}{l}\text { No. of years in } \\
\text { operation(2001- } \\
\text { 07) }\end{array}$ & 6 & 3 & 3 & 2 & 2 & $1 \frac{1}{2}$ & 6 & 5 & 3 & $1 \frac{1}{2}$ \\
\hline $\begin{array}{l}\text { Investment of } \\
\text { loan }\end{array}$ & $\begin{array}{l}\text { Purchase of } \\
\text { cattle }\end{array}$ & $\begin{array}{l}\text { Purchase } \\
\text { of sheep }\end{array}$ & $\begin{array}{l}\text { Purchase of } \\
\text { sheep }\end{array}$ & $\begin{array}{l}\text { Education/ } \\
\text { family } \\
\text { rituals }\end{array}$ & $\begin{array}{l}\text { Purchase } \\
\text { of cattle }\end{array}$ & $\begin{array}{l}\text { Education/ } \\
\text { family rituals }\end{array}$ & $\begin{array}{l}\text { Purchase } \\
\text { of cattle }\end{array}$ & $\begin{array}{l}\text { Purchase of } \\
\text { sheep }\end{array}$ & $\begin{array}{l}\text { To start food } \\
\text { processing } \\
\text { unit/tailoring } \\
\text { unit }\end{array}$ & $\begin{array}{l}\text { Education to } \\
\text { children }\end{array}$ \\
\hline
\end{tabular}


Table.2 Existing activities of the rural women in study area

\begin{tabular}{|l|l|l|}
\hline Existing activities & Number & Per cent \\
\hline Dairy farming & 62 & 31.00 \\
\hline Sheep rearing & 38 & 19.00 \\
\hline Tailoring & 24 & 12.00 \\
\hline Vermicompost & 03 & 1.50 \\
\hline Silk worm rearing & 13 & 6.50 \\
\hline Vegetable marketing & 60 & 30.00 \\
\hline Total & $\mathbf{2 0 0}$ & $\mathbf{1 0 0}$ \\
\hline
\end{tabular}

Table.3 Training programmes conducted to SHG women

\begin{tabular}{|c|c|c|c|}
\hline \multirow[t]{2}{*}{$\begin{array}{l}\text { Sl. } \\
\text { No. }\end{array}$} & \multirow[t]{2}{*}{ Training programmes } & \multicolumn{2}{|c|}{$\begin{array}{l}\text { Number of participants } \\
(n=200)\end{array}$} \\
\hline & & No. & Percent \\
\hline 1 & Processing of finger millet for value addition & 92 & 46 \\
\hline 2 & Processing of tomato based products & 24 & 12 \\
\hline 3 & Utilization of Baby corn/maize in the diet & 32 & 16 \\
\hline 4 & Cultivation and utilization of mushroom & 22 & 11 \\
\hline 5 & Fruits and vegetable processing & 30 & 15 \\
\hline & Total & 200 & 100 \\
\hline
\end{tabular}

Table.4 Finger millet products produced by SHG Women

\begin{tabular}{|l|l|l|l|l|l|}
\hline Products & Number & $\begin{array}{l}\text { Per } \\
\text { cent }\end{array}$ & $\begin{array}{l}\text { Year 2006 (in } \\
\text { kg) }\end{array}$ & $\begin{array}{l}\text { Year 2007 (in } \\
\text { kg) }\end{array}$ & $\begin{array}{l}\text { Total } \\
\text { Production (in } \\
\text { kg) }\end{array}$ \\
\hline $\begin{array}{l}\text { Finger millet } \\
\text { malt }\end{array}$ & 32 & 64 & 4,608 & $7,680(1.67)$ & 12,288 \\
\hline Hurihittu & 12 & 24 & 1,152 & $2,304(2.00)$ & 3,456 \\
\hline Malt chocolate & 6 & 12 & 48 & $96(2.00)$ & 144 \\
\hline Total & $\mathbf{5 0}$ & $\mathbf{1 0 0}$ & $\mathbf{5 , 8 0 8}$ & $\mathbf{1 0 , 0 8 0}(\mathbf{1 . 7 3})$ & $\mathbf{1 5 , 8 8 8}$ \\
\hline
\end{tabular}

Figures in parenthesis indicate enhancement in production. 
Table.5 Nutrient composition of finger millet value added products (per 100g)

\begin{tabular}{|l|l|l|l|}
\hline Nutrients & Finger millet malt & Hurihittu & Malt chocolate \\
\hline Energy(K.cal) & 327 & 330 & 417 \\
\hline Protein $(\mathrm{g})$ & 13 & 13 & 2.29 \\
\hline Fat $(\mathrm{g})$ & 01 & 01 & 14.01 \\
\hline Calcium (mg) & 306 & 263 & 265 \\
\hline Iron $(\mathbf{m g})$ & 04 & 05 & 06 \\
\hline
\end{tabular}

*Computed values

Table.6 Microbial load of finger millet products

\begin{tabular}{|c|c|c|}
\hline Products & Polythene pouches & Plastic box \\
\hline \multicolumn{3}{|l|}{ Mould $\left(10^{-2}\right)$} \\
\hline Finger millet malt & 0.25 & 0.20 \\
\hline \begin{tabular}{|l|} 
Hurihittu \\
\end{tabular} & 0.35 & 0.30 \\
\hline Malt chocolate & 0.05 & 0.40 \\
\hline \multicolumn{3}{|l|}{ Yeast $\left(10^{-2}\right)$} \\
\hline Finger millet malt & 8.75 & 0.70 \\
\hline Hurihittu & 9.75 & 0.60 \\
\hline Malt chocolate & 2.85 & 0.25 \\
\hline \multicolumn{3}{|c|}{ Bacterial counts $\left(10^{-3}\right)$} \\
\hline Finger millet malt & 1.85 & 0.85 \\
\hline Hurihittu & 2.15 & 0.95 \\
\hline Malt chocolate & 2.85 & 2.25 \\
\hline
\end{tabular}

Bacteria, moulds, yeast may infect food after harvesting, during its handling, processing and storage temperature, oxygen, light and duration of storage are the important factors that influence the type of microbial growth and spoilage of food during storage. Microbial load of different value added products of finger millet were stored for a period of 90 days in different packaging materials are presented in Table 6. Among the packages product stored in polythene covers showed higher microbial counts than products stored in packaging materials. This could be because of higher water vapour and gas transmission rate, poor tensile strength and sunlight / rays, causing spoilage of food products. Similar findings were observed by Chethana (2008) who conducted microbial analysis of stored products. Microbial load of the millets and legumes blended products had shown very low counts stored in plastic and steel boxes compared to polythene covers.

Among the products malt chocolate showed increase in number of microbial counts due to the method of preparation. Pressure of water and butter and absence of spices could have lead to increased microbial counts during storage compared to other products. The findings of this study are in line with findings of Devaraju et al., (2006).

Therefore from the present study it could be concluded that, rural women were able to generate substantial income, which can be used towards the family welfare. The training 
interventions by the research played a strategic role by increasing self-confidence of SHGs in undertaking small scale food processing of value added products of finger millet and capacity building of women at the village level and also improved nutritional status. Hence, administrators, policy makers and others involved in the capacity building of rural women should organize more capacity building programmes like demonstrations, trainings and others in processing and value addition of the agricultural products through group approach for social and economical empowerment of rural women

\section{References}

Chethana, K.P., 2008, Development of value added products from millets and legumes. MSc., Thesis, University of Agricultural Sciences, Bengaluru.

Deshpande, S. S., Mishra, A., and Mishra, M., 2003, Nutritional profile of farm women of Madhya Pradesh and impact of nutrition education on the inclusion of soya bean products. The Ind. J. Nutr. Dietet., 40: 185-187.

Devaraju, B., Begum, M., Begam, S., and Vidya, K., 2006, Storage and microbial quality of pasta from finger millet composite flour. Indian Food Packer., 48: 141-145.
Kavitha, V. and Deepa, P., 2013, Emerging preferences for processed foods among working and a non-working women. Annals of Agri-Bio-Research, 18(1): 9497.

Parvinder, S., Singh, G. P., and Jha, S. K., 2013, Impact of training programme on knowledge and adoption of preservation technologies among farm women: a comparative study. Ind. Res. J. ExtnEdu., 13(1): 96-100.

Raguprasad, K. P., Raj, G. M. P. and Gangadharappa, N.R., 2008, Mushroom cultivation using agricultural waste as sustainable livelihood, alternatives for resource poor SC/ST women, national seminar on SHG for rural upliftment emerging extension issues and strategies. Tiruchirapalli, Tamilnadu, pp: 149.

Rashmi, S. and Sinha, B. P., 2011, Entrepreneurial performance of women. Intr.J.Extn.Edu., 7: 8-20.

Savitha, C. M., Siddaramaiah, B. S., and Nataraju M. S., 2009, Development of a scale to measure the entrepreneurial behaviour of rural and urban women entrepreneurs. Mys. J. Agric. Sci., 43(1): 1190-121.

Seema, J., and Bhati, D. S., 2009, Entrepreneurship development among rural women through training. Current Advac. Agril. Sci., 1(2): 142-143.

\section{How to cite this article:}

Maruthesha, A.M., D. Vijayalakshmi and Preetham, S.M. 2018. Empowerment of Rural Women through Self-Help Groups and Value Addition of Millets in Bangalore Rural District of Karnataka, India. Int.J.Curr.Microbiol.App.Sci. 7(02): 1742-1748. doi: https://doi.org/10.20546/ijcmas.2018.702.211 